\title{
MEMBACA KECENDERUNGAN BENTUK DAN ISI KERAMIK KONTEMPORER INDONESIA
}

\author{
Taufik Akbar ${ }^{1}$ \\ (Program Studi Kriya Seni, FSRD, ISI Padangpanjang, taufik723@gmail.com,taufikakbar@isi-padangpanjang.ac.id, \\ 085292881636) \\ Hendratno ${ }^{2}$ \\ (Program Studi Kriya Seni, FSRD, ISI Padangpanjang, brkjayohendratno@gmail.com,hendratno@isi- \\ padangpanjang.ac.id,085263004642)
}

\begin{abstract}
This paper is a study about the tendency visual forms and content of contemporary ceramics in Indonesia. The research using a qualitative method with a historical approach as a documentation of the history of art ceramic in Indonesia. The result of this research contains: Contemporary ceramics in Indonesia for the past ten years tend to figurative forms, sculpture ceramics, and installation ceramics. Contemporary ceramics have strong expression value and it also influenced by art contemporary which is free in the visualization of the work. Then, the content of ceramics contemporary is personal and experience expression, aesthetic emphasis, local genius, gender issue, or theme of the social community. Next, ceramic art in the art contemporary era will continue with unique forms and content as a reflection of the artist paradigm and the zeitgeist.
\end{abstract}

Keywords: form, content, contemporary ceramics, expression

\section{ABSTRAK}

Makalah ini merupakan sebuah kajian tentang kecenderungan bentuk-bentuk visual dan isi keramik kontemporer di Indonesia. Penelitian dilakukan menggunakan metode kualitatif dengan pendekatan historis sebagai dokumentasi sejarah seni keramik Indonesia. Hasil kajian ini menunjukan bahwa: Keramik kontemporer Indonesia selama lebih kurang sepuluh tahun terakhir memiliki kecenderungan akan bentuk-bentuk figuratif, squplture dan keramik instalasi. Keramik kontemporer memiliki nilai ekspresi yang kuat dan banyak mendapat pengaruh kuat dari paradigma seni kontemporer yang bebas dari segi visualisasi karya. Selanjutnya keramik kontemporer Indonesia memiliki isi: ekspresi dan pengalaman personal, penekanan unsur dan prinsip estetik serta tema-tema kearifan lokal, isu gender atau kehidupan sosial masyarakat. Kedepannya, seni keramik di era seni kontemporer akan terus hadir dengan bentuk-bentuk dan tema unik sebagai refleksi atas paradigma berkarya seniman dan jiwa zaman yang melingkupinya.

Kata Kunci: bentuk, isi, keramik kontemporer, ekspresi

\section{PENDAHULUAN}

Keramik sebagai salah satu seni tertua sudah melalui perjalanan estetis yang panjang.
Dimulai dari sejarahnya sebagai barang kebutuhan rumah tangga hingga menjadi media ekspresi seni, tanpa disadari keramik 
hadir dengan bentuk-bentuk visual dan gaya pengungkapan yang unik saat ini. Di Amerika, diawali dengan gerakan art and craft movement menjadikan keramik sebagai cabang seni yang otonom. Gerakan ini melahirkan karya-karya keramik yang terlepas dari perdebatan antara "it is art or craft? Di Indonesia, walaupun tanpa gerakan sporadis dan frontal, keramik perlahan namun pasti juga sudah dianggap sebagai bidang seni yang berdiri sendiri.

Keramik menurut klasifikasinya termasuk dalam cabang kriya atau craft, namun harus disadari craft yang terdapat di barat sedikit berbeda dengan kriya di Indonesia. Craft dalam seni rupa barat merupakan cabang seni yang murni mengutamakan keterampilan tangan dalam perwujudan karyanya dengan berbagai material, sedangkan pengertian kriya di Indonesia tidak sebatas pada penguasaan keterampilan semata. Kriya kental akan muatan budaya dan nilai-nilai filosofis khas masyarakat timur. Keterampilan tangan memang menjadi keutamaan, namun bukan menjadi poin satu-satunya dalam berkarya kriya (Satrio, 2013:167). Pemahaman yang demikian dapat dimaklumi karena memang karya kriya Indonesia pada awalnya sarat akan makna-makna filosofis dan nilai-nilai budaya.

Karya kriya berbasis material tanah liat disebut dengan kriya keramik, singkatnya dapat disebut "keramik" atau "gerabah" saja tergantung jenisnya. Di Indonesia jika dirunut menurut sejarahnya keramik umum yang dibuat adalah gerabah, yaitu jenis keramik dengan bakaran rendah dan tanpa gelasir. Pembuatan gerabah ini bahkan sudah menjadi tradisi turun-temurun di beberapa daerah, kecuali di singkawang kalimantan Barat dimana sejak perantau Cina datang mereka sudah mengembangkan keramik dengan bakaran tinggi dan bergelasir.

Seiring perubahan zaman serta kemajuan teknologi membuat keramik Indonesia berkembang dan seni keramik pun mulai banyak diminati sebagai media seni. Didirikannya Balai Besar Keramik Bandung sebagai pusat pengembangan keramik Indonesia membuat keramik yang ada tidak lagi sebatas gerabah. Selain itu perkembangan pendidikan seni juga memberi pengaruh estetis melalui bentuk-bentuk karya yang dihasilkan oleh pengajar maupun siswa/mahasiswa institusi pendidikan seni tersebut.

Dengan mulai diajarkannya keramik di sekolah-sekolah maupun kampus-kampus seni, maka secara tidak langsung seniman-seniman keramik (keramikus) semakin banyak bermunculan, disamping tentunya juga seniman yang belajar secara otodidak terus tumbuh. Menurut Mochtar Kusuma Atmaja awal periode kemunculan seniman/perajin keramik terjadi sekitar tahun 1985 (Yustana, 2012:64). Dari tahun tersebut hingga saat ini tentu seni keramik Indonesia terus berkembang mengikuti jiwa zaman (zeigest)nya masing-masing. Perkembangan tesebut dapat dilihat dari karya-karya yang dihasilkan.

Jika Mochtar Kusuma Atmaja membagi sejarah keramik Indonesia berdasarkan periodesisasi aktivitas keseniannya, maka seni keramik juga dapat dibagi berdasarkan pengkategorian karyakaryanya. Secara garis besar klasifikasi seni keramik Indonesia menurut ciri karya dan waktu berkembangnya dapat dibagi menjadi tiga golongan yaitu:

1. Seni Keramik Tradisional (pra-sejarahsekarang)

2. Seni Keramik Modern (1975-2009) 
3. Seni Keramik Kontemporer (2010sekarang)

Seni keramik tradisional Indonesia bercirikan karya-karya keramik yang lahir dari kebiasaan masyarakat yang turun temurun. Jenis keramik tradisional umumnya adalah gerabah dengan karya/produk yang sudah umum kita lihat seperti kendi, gentong dan belanga. Keramik tradisional gerabah masih dibuat hingga sekarang bahkan dikembangkan menjadi berbagai bentuk yang unik sebagai barang seni kerajinan yang menunjang pariwisata suatu daerah.

Keramik modern merupakan efek langsung dari kemajuan pendidikan seni. Seni keramik modern didominasi dari keramikus Indonesia senior yang lahir dari lembaga pendidikan seni seperti Hildawati Soemantri, Suyatna, Hendrawan Riyanto, Noor Sudiyati, Ponimin hingga F. Widayanto. Hildawati Soemantri dapat dikatakan sebagai tonggak pencetus keramik modern Indonesia melalui karya-karya yang dibawanya setelah belajar di Amerika tahun 1975.

Seni keramik modern dapat diartikan sebagai seni keramik yang mengedepankan daya kreatif untuk menghasilkan bentukbentuk baru. Sesuai dengan karakter seni rupa modern yaitu "kreativitas". Bukti kreativitas tersebut dapat dilihat pada karya keramik dari nama-nama keramikus di atas. Di era keramik modern hadir bentuk-bentuk keramik baru seperti bentuk panel layaknya lukisan, keramik figuratif, hingga keramik dengan bentukbentuk simbolis.

Dunia seni bukanlah sesuatu yang statis. Seni terus berubah baik dari segi karya maupun wacana yang diusung. Melampaui seni rupa modern kemudian berkembanglah seni rupa kontemporer. Kehadiran seni rupa kontemporer entah sejalan atau tidak bersamaan dengan keberadaan seni keramik kontemporer atau biasanya disingkat keramik kontemporer.

Berbicara mengenai keramik kontemporer Indonesia dapat dimulai dari tahun 2011 dimana ketika itu digelar Jakarta Ceramic Contemporary Biennale \#1 dan masih berlangsung hingga sekarang. Perjalanan sepuluh tahun keramik kontemporer Indonesia tentu banyak menghadirkan karya-karya dengan bentuk pengungkapan yang up to date. Bentuk-bentuk keramik kontemporer ini layak dikaji karena seni kontemporer tidak hanya menghadirkan kebaruan dari wujud visual dan kreasi, namun sangat tematik, konseptual dan mengusung wacana atau narasi kekinian. Jadi tulisan ini akan membahas kecenderungan bentuk dalam seni keramik kontemporer Indonesia termasuk seniman-senimannya. Selain itu dalam kajian ini juga diulas tentang peta penyebaran pertumbuhan keramik kontemporer di Indonesia.

\section{METODE}

Kecenderungan bentuk keramik kontemporer Indonesia dikaji menggunakan metode penelitian kualitatif dengan pendekatan sejarah. Objek penelitian adalah karya keramik kontemporer Indonesia sepuluh tahun terakhir. Untuk itu akan diambil beberapa sampel dari populasi karya keramikus Indonesia yang akan dianalisis bentuk dan isi karyanya.

Pengambilan sampel beberapa keramik disini bukan untuk menyama ratakan persepsi, melainkan untuk mencari sesuatu yang unik dari karya-karya seni keramik kontemporer.

Sampel karya keramik yang diteliti dapat didasarkan pada tujuan penelitian/kajian atau purposive sampling. Untuk itu karya yang 
akan dikaji adalah keramik-keramik yang dekat dan kuat akan ciri seni kontemporer itu sendiri. Ciri atau karakter seni kontemporer yang paling menonjol adalah "keleluasaan" dalam menciptakan karya tanpa harus dibatasi pakem cabang seni tertentu. Dalam seni kontemporer dapat disimpulkan batasan antar cabangcabang seni menjadi sedikit kabur. Oleh karena itu keramik kontemporer juga terkena imbas dari semangat "keleluasaan" melalui bentuk visual karyanya.

Untuk mengetahui kecenderungan bentuk-bentuk keramik kontemporer ini diperlukan landasan teori tentang bentukseni. Terdapat banyak teori tentang bentuk dalam seni, teori bentuk yang sudah berlangsung lama pun hingga saat ini masih sering digunakan dalam kajian-kajian seni rupa. Dalam ilmu keramik belum ada teori khusus yang membahas tentang bentuk suatu karya keramik, namun pendapat Louisa Taylor tentang pembagian tipe keramik dapat dijadikan rujukan, karena tipe-tipe keramik ini didasarkan pada wujud visual suatu keramik. Menurut Louisa Taylor (2011:10-11), tipe karya keramik menurut bentuk visualnya dapat dibagi menjadi enam tipe yaitu:

1. Keramik Tableware

2. Vessel (Vas)

3. Keramik Dekoratif

4. Keramik Figuratif

5. Keramik Squlpture

6. Keramik Instalasi

Dari eman kategori tipe keramik di atas rasanya sudah mengakomodir bebagai macam bentuk pengungkapan/ekspresi yang dihadirkan seniman melalui keramik kontemporer, termasuk keramik kategori tableware (peralatan makan). Hal itu dikarenakan era seni kontemporer yang cenderung memegang prinsip "apapun bisa" menjadi karya. Selain itu dalam tulisan ini juga akan diulas mengenai isi keramik tersebut, isi disini dapat berarti tema atau makna yang terkandung dalam suatu karya (keramik). Makna dapat berupa konsep pemikiran yang tersirat dari visualisasi bentuk karya (Salma \& Eskak, 2016:5). Makna sebuah karya dapat berupa pesan, cerita atau juga dapat berupa konsep pemikiran yang berhubungan dengan unsur-unsur serta konsep-konsep estetik.

\section{HASIL DAN PEMBAHASAN \\ Keramik Kontemporer Indonesia (antara Art, Craft \& Design)}

Jika kriya merupakan bidang ilmu seni yang beririsan dengan cabang seni murni (art) dan desain (design), maka keramik kontemporer yang berkembang hingga kini dapat dikatakan merupakan irisan dari art, craft dan design. Menurut Asmudjo Jono Irianto pada kuratorial Pameran JCCB \#3, keramik kontemporer dapat dibagi ke dalam tiga kelompok tersebut. Hal itu karena karyakarya yang mewarnai seni keramik kontemporer termasuk di Indonesia pada dasarnya memiliki kecenderungan pada tiga cabang seni ini (art, craft, design).

Keramik kontemporer yang condong ke art adalah karya-karya keramik yang tedensi ekspresi pribadinya lebih kuat dibandingkan aspek fungsi atau dekorasi. Jika mau jujur bahkan kedua aspek tersebut ada yang nyaris dihilangkan sama sekali oleh si seniman pada perwujudan karyanya. Keramik keramik semacam ini contohnya dapat dilihat pada keramik figuratif maupun instalasi. Dalam medan ilmu yang lebih luas lagi keramikkeramik yang melompat ke kelompok art biasa disebut dengan kriya seni, yaitu karya kriya yang lebih menekankan ekspresi seniman dan 
nilai keindahan dibandikan aspek fungsi karya secara fisik.

Fenomena karya kriya yang mengarah ke art ini sebenarnya tidak hanya melanda keramik, namun cabang kriya lainnya seperti kayu, logam dan tekstil. Perubahan cara pandang dalam berkarya kriya inilah yang dapat disebut sebagai paradigma contemporary craft atau kriya kontemporer. Pertanyaan yang kemudian muncul mengapa keramik kontemporer seolah-olah bisa berjalan sendiri? Hal ini sepertinya lebih karena paradigma seniman keramik yang berkarya dalam medan seni rupa secara umum sudah lepas dari pertanyaan apakah keramik ini kriya atau bukan. Jawaban lain yang masuk akal adalah banyaknya perupa atau seniman yang tertarik akan keramik berasal dari latar belakang yang beragam.

Kategori keramik kontemporer selanjutnya adalah keramik desain. Keramik desain memiliki kecenderungan dan berbasis pada desain. Asmudjo Jono irianto dalam tulisannya pada kurasi The 3rd Jakarta Contemporary Ceramics Biennale:"Coefficient of Expansion" menuliskan bahwa seni keramik dalam konteks desain dapat dibagi dua metode yaitu craft-based design dan factory-based design (Irianto, 2014:xxix). Metode pertama dapat dikatakan sebagai karya kriya keramik dekoratif atau tableware yang tidak diproduksi massal, sedangkan metode kedua (factorybased design) adalah keramik pabrikan yang kerap dibuat massal. Keramik craft-based design yang dirancang dan dibuat sendiri oleh seniman (designer-maker) lah yang lebih ditekankan sebagai seni keramik kontemporer. Ciri khas keramik ini adalah karya-karyanya yang bersih dan rapi, baik sebagai keramik dekoratif untuk interior maupun keramik fungsional.
Kategori keramik berikutnya dalam ranah keramik kontemporer Indonesia adalah keramik yang condong ke craft. Keramik kategori ini dapat dikatakan sebagai keramik yang benar-benar mengutamakan karakter craft atau kriya dalam perciptaan karyakaryanya yang mengedepankan teknik atau keterampilan tangan, nilai guna "usefully" sebuah karya dan nilai estetik dari bentuk visual yang ditampilkan. Dalam konteks kriya di Indonesia, mungkin ketiga aspek ini dapat ditambah satu aspek lagi yaitu berlatar belakang nilai-nilai budaya timur.

\section{Keramik Ekspresi sebaga awal kemunculan Keramik Kontemporer}

Dalam perkembangan karya kriya termasuk keramik di Indonesia terjadii polarisasi yang membagi karya menjadi dua cabang yaitu karya fungsional dan karya ekspresi. Kriya atau seni kriya sebagai media ekspresi perkembangannya memiliki ruang lingkup dan berbagai kemungkinan yang terbuka (Rispul, 2012:96)

Perubahan dan perkembangan karya kriya terjadi karena berbagai faktor seperti gerakan dan perkembangan seni rupa,, kreasi dan kreativitas seniman serta pengaruh dunia pendidikan seni. Selain itu seniman terkadang juga mengalami kebosanan pada karyakaryanya dan butuh eksplorasi baru dalam berkarya. Oleh karenanya seniman atau perupa juga disebut creator yang selalu bergelut dengan kreativitas melalui ide, eksperimen dan inovasi (Fitriani, 2017:68). Berbagai faktor ini pada akhirnya sedikit menghilangkan batasan-batasan antar cabang seni dan membuat karya kriya terutama keramik tidak lagi menonjolkan aspek fungsi namun juga ekspresi.

Keramik ekspresi dapat dikatakan sebagai karya seni keramik yang memiliki 
kekuatan pada ungkapan jiwa seniman yang disalurkan pada karya (keramik) yang diwujudkan. Bentuk ungkapan ini dapat berupa apa saja. Dapat juga melalui keramik ekspresi seniman berusaha untuk menyampaikan pesan, atau sebagai refleksi atas suatu kondisi dan keadaan yang dirasakan. Paradigm berkarya seperti ini tentu saja lebih mendekati pada karakter karya seni murni sekaligus menjadi bukti adanya perkembangan seni yang menolak sekat-sekat dalam berkarya seni rupa. Bukti sejarah perkembangan tersebut setidaknya dapat dilihat pada kemunculan GSRB (Gerakan Seni Rupa Baru) Indonesia sekitar tahun 1975.

Seniman yang menekuni keramik sebagai media ekspresi setelah era GSRB akhirnya terus tumbuh dengan karya-karya keramik ekspresi yang menjadi awal tonggak kemunculan seni keramik kontemporer Indonesia.

\section{Kecenderungan Bentuk Visual dan Isi Keramik Kontemporer Indonesia}

Istilah keramik kontemporer mulai

akrab didengar dalam kancah seni rupa Indonesia pada akhir tahun 2009. Pada tahun tersebut beberapa akademisi dan praktisi keramik tanah air berkolaborasi menggelar Pameran Jakarta Contemporary Biennale Ceramic disingkat JCCB untuk pertama kalinya di Galeri North Art Space, Pasar Seni Ancol. Walaupun demikian sebenarnya jika dilihat dari perkembangan karya-karya keramik dalam berbagai pameran seni rupa tanah air, bentuk keramik yang dihadirkan sudah mengarah ke ciri "kontemporer" sejak era 90-an, hanya saja istilah kontemporer baru booming sejak tahun 2000-an. Dalam ruang lingkup yang lebih luas bahkan seni rupa kontemporer sendiri sudah mulai berkembang sejak dekade 70-an (Dewi,
2017:24), namun belum banyak menyentuh seni keramik.

Sebelum membahas tentang bentuk keramik kontemporer perlu diketahui bahwa peta pertumbuhan karya keramik modern dan kontemporer di Indonesia dapat dikatakan berada di tiga daerah, yaitu Yogyakarya, Bandung dan Jakarta. Ketiga daerah ini selalu melahirkan seniman atau perupa keramik yang aktif membawa keramik dalam kancah perhelatan seni rupa nasional dan internasional. Dalam perkembangannya karyakarya keramik dari ketiga daerah tersebut memiliki ciri khas dan karakter tersendiri yang membedakannya satu sama lain.

Keramik-keramik dari perupa Yogyakarta umumnya memiliki kekuatan akan ungkapan atau gejolak emosi jiwa perupa. Ciri khas ini mungkin dipengaruhi oleh sejarah nafas seni rupa Yogyakarta yang lebih dekat pada filosofi seni "jiwa ketok" yang dipelopori Sudjojono. Dari segi bentuk keramik perupa Yogyakarta juga kaya akan keramik dengan bentuk-bentuk figure tertentu.

Sedikit berbeda dengan Yogyakarta, karya keramik perupa Bandung atau yang mengenyam pendidikan seni di Bandung memiliki kekuatan pada aspek bentuk yang mengedepankan susunan formal (formalistik). Keramik perupa Bandung juga umumnya kaya akan permainan teknik. Sejurus dengan hal tersebut karya keramik dari seniman/perupa Jakarta sedikit terpengaruh atau dapat dikatakan mengikuti kecenderungan karakter keramik perupa asal Bandung yang formalistik, walaupun tidak dapat digeneralisasi. Hal tersebut dikarenakan selain faktor kedekatan wilayah perkembangan seni keramik di Jakarta juga dipelopori oleh beberapa seniman yang berasal dari Bandung. 
Dalam zaman seni rupa kontemporer saat ini, perbandingan karakter karya keramik dari Yogyakarta, Bandung dan Jakarta memang tidak terlalu mencolok, tetapi dengan kuatnya akar ideologi berkesenian di wilayah tersebut dan ditunjang pengaruh institusi pendidikan yang mempeloporinya (ISI Yogyakarta, ITB, Institut Kesenian Jakarta), maka ciri khas ketiga wilayah tersebut masih dapat ditemui pada karya-karya keramik kontemporer di Indonesia.

Keramik kontemporer merupakan kelanjutan atau perpanjangan era keramik modern yang mulai pesat, namun berjalan sendiri-sendiri dalam berbagai pameran seni rupa. Beberapa keramik dengan bentuk baru pada akhir 90-an sampai awal 2000 lebih banyak hadir dalam pameran-pameran kriya skala kampus hingga regional.

Sepanjang tahun 2000-2010 bayaknya keramikus-keramikus muda dengan pembaruan keramiknya, serta masih eksisnya keramikus modern di tengah masuknya era seni rupa kontemporer membuat seni keramik kontemporer itu sendiri harus "dipetakan" untuk mendapatkan identitas karakter dan nilai estetisnya. "JCCB \#1 adalah upaya untuk memetakan pencapaian seni keramik kontemporer yang tengah berkembang (Sarasvati, 2013:1). Jadi, dapat disimpulkan bahwa pameran JCCB \#1 merupakan wujud dari pemetaan tersebut.

Setelah dilakukan pertama kali tahun 2009 JCCB sudah berjalan lima kali hingga tahun 2019 yang berubah menjadi Indonesia Ceramics Contemporary Biennale. Walaupun bukan satu-satunya pameran yang menghadirkan keramik kontemporer, namun karya-karya yang dipamerkan dalam JCCB ini dapat menjadi acuan untuk melihat sejauh mana perkembangan bentuk-bentuk keramik kontemporer Indonesia. Dari sepanjang sepuluh tahun tersebut sebenarnya dapat dikatakan tidak ada bentuk-bentuk yang mendominasi, tetapi kecenderungan mayoritas bentuk-bentuk keramik kontemporer dapat dibagi menjadi tiga tipe, yaitu bentuk keramik figuratif, keramik squlpture keramik dengan bentuk-bentuk instalasi.

\section{a. Keramik Figuratif}

Pada Pameran JCCB \#1 menghadirkan keramik kontemporer dari 40 perupa Indonesia dan mancanegara yang mengusung tema Ceramic Art : In Between. Dari tema tersebut dapat diartikan pameran ini ingin menunjukan posisi seni keramik Indonesia yang berada di antara dikotomi art and craft. Meskipun demikian jika melihat pada karyakarya perupa Indonesia yang ditampilkan pada pameran tersebut, dapat dilkatakan kecenderungan bentuk keramik kontemporer diawali dan didominasi bentuk-bentuk keramik figuratif dengan tema yang lebih mengedepankan ekspresi, ide dan pengalaman personal. Keramik figuratif disini maksudnya adalah keramik yang berbentuk figur-figur tertentu, tidak hanya manusia namun juga bisa hewan atau makhluk mitologi sekalipun. Salah satu karya tersebut dapat dilihat dari keramik Titarubi berjudul "Bayang-Bayang Maha Kecil"

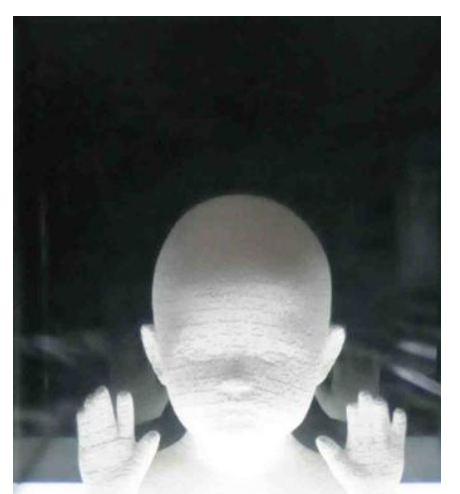

Gambar 1. Detail karya Titarubi "Bayang-Bayang Maha Kecil" Titarubi "Bayang-Bayang Maha Kecil" (Serial 9 of 9), $130 \times 40 \times 40 \mathrm{~cm}$, Ceramic, Acrylic, MDF and Lamp, 2009 
Keramik Titarubi di atas walaupun menggabungkan beberapa media namun yang menjadi fokus karyanya adalah bentuk figur keramik berbentuk kepala anak kecil dengan kedua telapak tangan yang solah-olah diangkat sebahu. Bentuk keramik ini diberi tulisan arab pada permukaannya. Dalam statement si seniman, karya ini terinspirasi dari kedua anaknya, disamping itu juga merupakan refleksi dirinya akan iman, keraguan dan harapan yang ia miliki (Titarubi, 2010:1). Dari karya tersebut, Titarubi berusaha mengekspresikan kegelisan dirinya yang bersifat personal melalui keramik, sesuatu yang akrab dengan keramik-keramik modern Indonesia.

Bukti kecendrungan bentuk keramik figuratif ini juga dapat dilihat pada karya Endang Lestari, Donna Prawitta Arisuuta dan Jenny Lee. Keramik-keramik dari para seniman ini akrab dengan bentuk-bentuk figur manusia, dewa dewi atau makhluk lainnya.

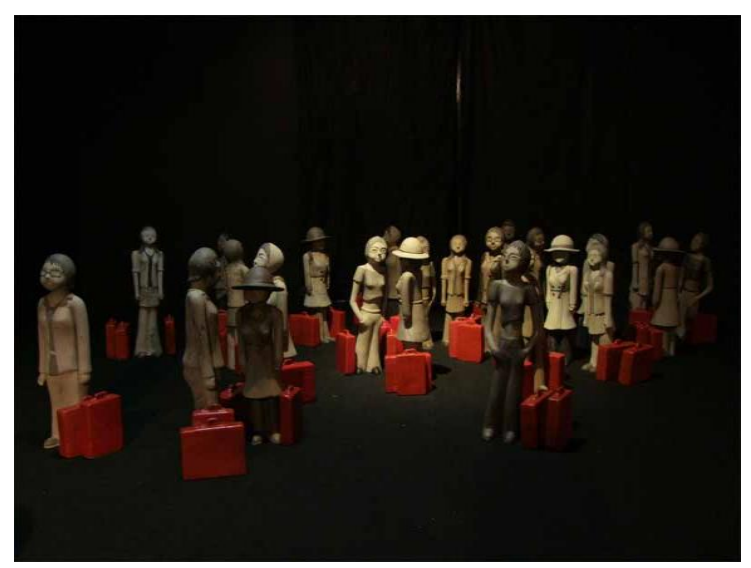

Gambar 2. Endang Lestari, Koper Merah dan Perempuan Pekerja, Keramik Stoneware, $40 \mathrm{~cm} \times 15$ cm, 2009

Karya Endang Lestari dengan judul Koper Merah dan Perempuan Pekerja memamerkan 40-50 figur perempuan dengan berbagai karakter dan style namun kesemuanya memegang atau memakai koper. Karya ini bercerita tentang perjalanan perempuan dengan koper merah, dilatar belakangi pengalamannya dengan sesama perempuan pekerja(Lestari, 2010:1). Walaupun nampak mengusung isu gender, lagi-lagi keramik figuratif ini berisi refleksi seniman untuk mengekspresikan sesuatu yang dekat dengan kehidupan personal atau pengalaman pribadinya.

Jenny Lee juga menegaskan kecenderungan bentuk-bentuk figuratif pada awal keberadaan keramik kontemporer Indonesia lewat karyanya "Waiting". Keramik ini berwujud visual empat figur perempuan yang duduk seolah-olah menunggu seseorang, namun melalui karya ini Jenny Lee sangat kuat mengangkat tema sosial tentang posisi perempuan dalam tatanan kehidupan masyarakat. Dalam deskripsi karyanya Jenny Lee ingin berbicara tentang identitas sosial yang membentuk peran dan tempat seorang wanita di komunitas tempat ia tinggal (Lee, 2010:1).

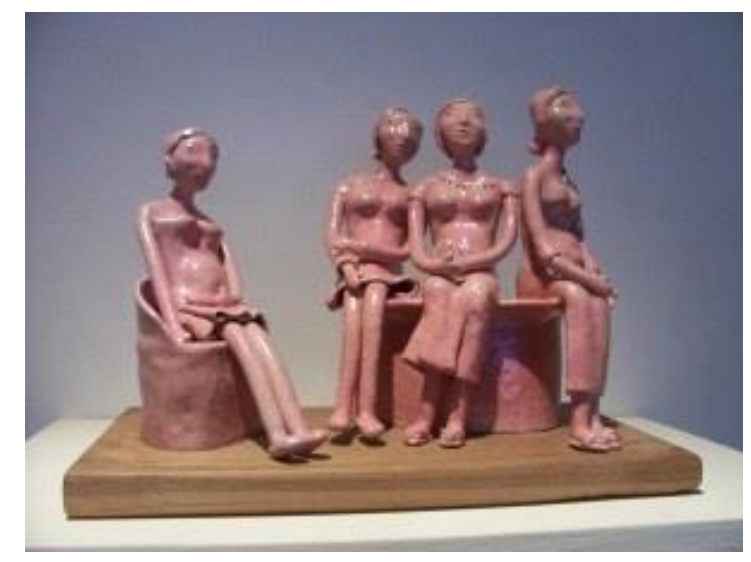

Gambar 3. Jenny Lee, Waiting, Stoneware\& Kayu, $30 \times 15$ $\times 22 \mathrm{~cm}, 2009$

Keramik kontemporer dengan bentuk figuratif yang berisi ekspresi personal atau refleksi kehidupan sosial yang dekat dengan seniman sebenarnya sudah dimulai sekitar sebelum tahun 2000. Keramikus F. Widayanto bahkan lebih dulu identik dengan patung- 
patung keramik figuratif seperti keramik seri Ganesha atau Loro Blonyo ciptaannya, selain itu keramikus lain seperti Noor Sudiyati juga pernah menghadirkan keramik figuratif walaupun dengan wujud dan karakter yang berbeda. Lebih dari itu jika dilihat secara historis maraknya bentuk-bentuk figuratif di awal seni keramik kontemporer Indoesia lahir karena masih kuatnya pengaruh keramik modern dengan bentuk serupa.

$$
\text { Kecenderungan bentuk figuratif }
$$
dalam awal pertumbuhan keramik kontemporer Indonesia merupakan pengaruh dari mulai pudarnya batasan-batasan dan penggolongan cabang-cabang seni. Keramik figuratif yang hadir sedikit banyak menyerupai karya seni patung yang tergolong seni murni, sangat jauh berbeda dengan pakem keramik yang lahir dari cabang kriya.

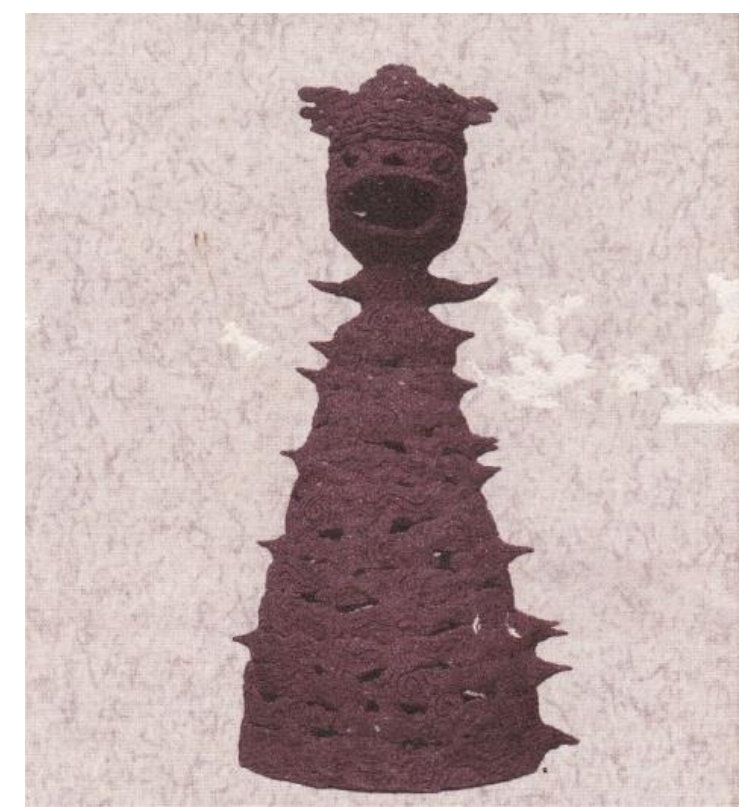

Gambar 4. Noor Sudiyati, "Ngomong", 53 × $25 \mathrm{~cm}$, Stoneware, 1998

Dengan tanpa mengesampingkan bentuk-bentuk pengungkapan lainnya, harus diakui pertumbuhan keramik kontemporer Indonesia diawali dengan keramik-keramik figuratif yang berisi tema ekspresi personal seniman akan pengalaman pribadi atau lingkungan sosial sekitarnya. Selanjutnya keramik-keramik figuratif baik manusia, hewan dan lainnya selalu tumbuh dan mengisi ranah keramik kontemporer Indonesia tidak hanya dalam pameran JCCB, namun pada pameranpameran seni rupa lainnya.

\section{b. Keramik Squlpture}

Squlpture dalam bahasa Indonesia berarti pattung atau seni patung, namun dalam ilmu keramik squlpture bukan patung. Keramik squlture dapat diartikan sebagai keramik ekspresi seniman yang dapat dinikmati secara visual dan memiliki tujuan estetis (Louisa Taylor, 2011:11). Squlpture dalam keramik lebih merujuk pada keramik yang dibuat seniman dengan berbagai teknik dengan bentuk-bentuk non figuratif dan dinamis, serta memiliki tujuan estetis.

Keramik Squlpture dalam keramik konteporer lebih menekankan pada penguasaan keterampilan tangan seniman untuk membangun berbagai bentuk keramik menjadi beragam bentuk-bentuk estetis tanpa harus menekankan pada fungsi. Dengan kata lain keterampilan tangan atau "craftmanship" menjadi poin utama dalam penciptaan keramik squlpture.

Keramik harus diakui tidak bisa lepas dari induknya yaitu kriya/craft. Ciri khas atau karakter karya kriya adalah kerja tangan dengan tingkat keterampilan yang tinggi dalam sebuah penciptaan karya. Seni rupa kontemporer tidak serta merta dapat menghilangkan karakter tersebut. walaupun keramik kontemporer memiliki kecondongan akan ekspresi dan ide seniman dalam karyanya, tetap saja untuk mewujudkannya dibutuhkan keterampilan tangan atau 
penguasaan teknik karena bersinggungan dengan material tanah liat yang walaupun lentur namun juga riskan. Dalam kuratorialnya pada Jakarta Contemporary Ceramic Biennale \#2, Sudjud Dartanto menegaskan bahwa walaupun keramik terbuka terhadap berbagai wacana dalam karyanya, keramik seni tetap memperhatikan sejarah material keramik itu sendiri ( Dartanto, 2013:16).

Pameran JCCB \#2 yang mengankat tema "Crafting Identity". Tema ini sebenarnya tidak merujuk pada kemampuan menciptakan karya dengan keterampilan (craftmaship), namun lebih kepada proses keterampilan menciptakan identity atau identitas dari keramik itu sendiri (Dartanto, 2013:10). Walaupun begitu dapat dilihat pada pameran ini bagaimana karya-karya seni keramik yang menonjolkan keterampilan hadir dengan berbagai wujud visual yang "halus". Bentukbentuk figuratif memang masih ada, namun keramik yang memperlihatkan kualitas teknik dan keunggulan craftmaship memberi kesegaran tersendiri. Karya tersebut dibuat dengan berbagai teknik pengerjaan dan penyajian tanpa meninggalkan karakter khas keramik.

Keramik yang berbahan utama tanah liat (clays) dalam perwujudan karyanya memiliki beragam teknik pembuatan baik dengan tangan langsung (hand building) maupun teknik pembuatan yang dibantu dengan mesin. Berbagai teknik tersebut pun dapat dikombinasikan untuk membangun, menyusun atau menciptakan berbagai bentukbentuk estetis. Oleh karena keragaman sifat membangun dan menyusun tanah liat itulah maka keramik tipe ini disebut squlpture.

Jika keramik figuratif hadir dengan isi tema karya yang personal hingga menyentuh isu sosial, keramik squlpture lebih berisi susunan unsur-unsur rupa/visual untuk mengedepankan prinsip-prinsip estetis. Keramik dengan bentuk squlpture dapat kita ulas beberapa diantaranya karya Natas Setiabudhi, Ahadiat Joedawinata hingga keramikus muda Nur Hardiansyah.

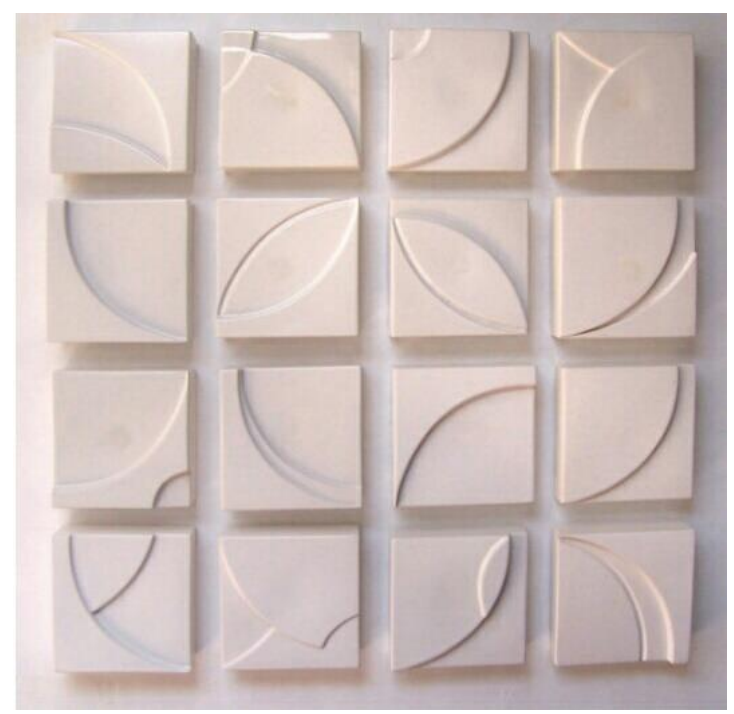

Gambar 5. Natas Setiabudhi, Move \#2, stonewareclay, zircon glaze $1230^{\circ} \mathrm{C}$, slip casting and slabbing 2011

Karya Natas Setiabudhi yang mengenyam pendidikan di Bandung dengan judul "Move \#2" ini dapat dijadikan contoh bagaimana keterampilan tangan dalam berkarya keramik menghasilkan karya yang rapi, halus dan memperlihatkan ketelatenan. Karya Natas memiliki bentuk susunan enam belas panel keramik dengan dekorasi lengkung di setiap panelnya. Keramik ini dibuat dengan teknik cetak tuang danslab. Kedua teknik ini membutuhkan ketelitian karena mengejar kerapian karya. Mungkin ada yang berpendapat keramik ini masuk dalam kategori keramik dekoratif, namun jika melihat bentuk visual dan penyajiannya secara keseluruhan keramik ini masih masuk ke dalam kategori squlpture.

Dari segi isi keramik Natas ini lebih mengutamakan keindahan estetik melalui 
pengorganisasian unsur-unsur dan prinsip estetik untuk membangun karya seni yang baik. Karya-karya semacam ini seperti ciri karya seni dengan gaya susunan formal menurut Edmund Burke Feldman. Seni keramik memang menawarkan banyak kemungkinan dan pilihan dan di tengan era seni rupa kontemporer berbagai kemungkinan tersebut menjadi anything goes atau apapun bisa.

Keramik squlpture lain yang dapat dijadikan contoh adalah karya Ahadiat Joedawinata. Beliau merupakan perupa keramik yang konsisten dengan karya-karya yang menampilkan bentuk-bentuk estetis melalui permainan teknik dan tekstur keramik. Ahadiat begitu terobsesi dengan ketipisan keramik yang dikerjakan dengan teknik pijit.

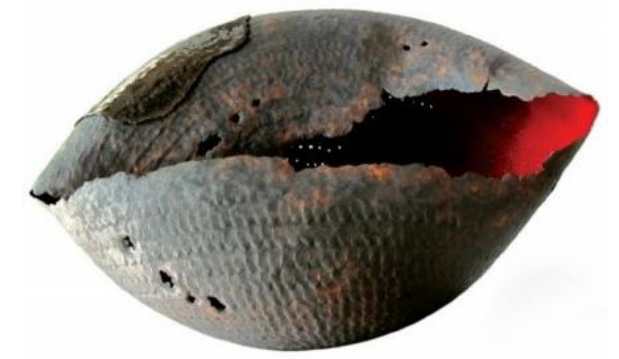

Gambar 6. Ahadiat Joedawinata, Energi dalam Retakan, stoneware, pinch, $25 \times 23 \times 28 \mathrm{~cm}, 2012$

Karya Ahadiat dengan bentuk seperti cangkang di atas memperlihatkan penguasaan keterampilan teknik pinch atau pijit dalam pembentukan keramik. Teknik pijit merupakan teknik paling dasar pengerjaan keramik metode hand building. Walaupun sepertinya sederhana teknik ini membutuhkan ketelatenan khusus karena semakin tipis body keramik maka semakin tinggi pula resiko kegagalannya. Selain tipis karya Ahadiat juga memiliki tekstur kasar yang sebenarnya merupakan jejak pijitan tangannya ketika memijit dan membentuk tanah liat. Dengan judul 'Energi Dalam Rekahan" seolah-olah sang seniman ingin menyampaikan bahwa ada energi kuat untuk membentuk karya keramik yang tipis. Dapat pula energi yang ia maksud disimbolkan dengan gelasir warna merah yang terdapat pada bagian dalam karyanya yang seperti merekah. makna personal yang disampaikan hanya lewat unsur-unsur rupa.

Keramik dengan bentuk-bentuk yang bebas dan non-representasional serta menonjolkan teknik serta tekstur ini jika ditinjau dari sejarah juga serupa dengan keramik-keramik Noor Sudiyati, hanya saja keramik Ahadiat memberikan sentuhan gelasir pada karyanya. selain itu dari segi isi atau makna keramik Noor Sudiyati juga kerap mengungkapkannya dengan elemen dasar seni rupa yaitu tekstur. Seni memang tidak harus meniru karya seni tidak wajib seperti cerita bergambar. Ekspresi seni dapat diterjemahkan dengan elemen yang sederhana, bahkan dengan sebuah garis sekalipun.

Karya dengan kecenderungan bentuk squlpture lainnya yang menghiasi dunia seni keramik kontemporer Indonesia adalah dari seoran keramikus muda Nur Hardiansyah. Pada perhelatan JCCB \#3 di tahun 2014 melalui karya 'Story" dapat dilihat bagaimana ia memadukan squlpture dengan keterampilan teknik putar keramik sehingga menampilkan karya yang tidak hanya menarik secara estetis, namun baginya juga memiliki cerita.

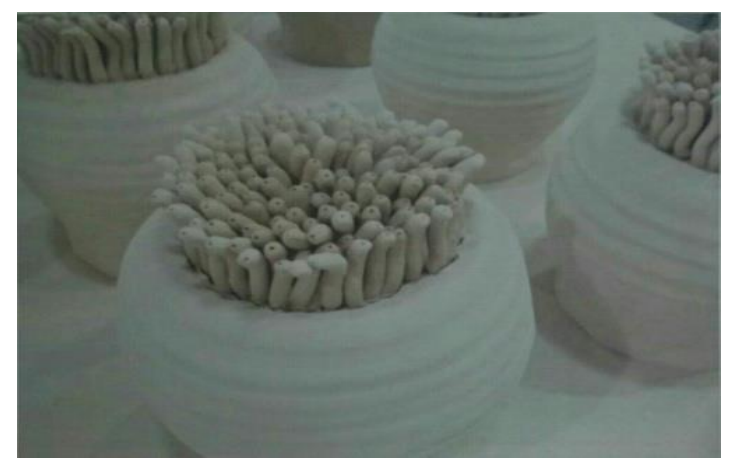

Gambar 7. Nur Hardiansyah, Story, stoneware, $100 \times 60 \times 30 \mathrm{~cm}, 2014$ 
Karya Nur Hardiansyah di atas berisi cerita pengalaman personal masa kecilnya tentang Anemon Laut. Anemon laut adalah hewan laut yang secara visual tampak seperti tumbuhan dan tidak mengesankan figur tertentu. Bagi sang seniman, Anemon laut dapat mewakili pengalaman sosial manusia melalui gerakan dinamis dan ekspresif dan ia berusaha mengambil bentuk, tekstur dan gestur baru dari anemon menjadi bentuk baru (Hardiansyah, 2015:121). Bentuk dan karakter unik dari anemon laut ini kemudian melekat dengan dirinya sekaligus menjadi personal identity seorang Nur Hardiansyah sebagai seniman keramik.

\section{c. Keramik Instalasi}

Kecendrungan seni keramik kontemporer Indonesia berikutnya adalah keramik instalasi. Keramik instalasi adalah keramik yang terdiri dari satu objek atau beberapa objek yang disusun, dipasang atau ditempatkan pada suatu space yang kemudian menghasilkan suatu bentuk karya dengan berbagai konteks dan makna tertentu. Karya instalasi dapat juga merupakan relasi yang kuat antara suatu objek karya dengan lingkungan tempat karya dipasang (Louisa Taylor, 2011:11) Jenis keramik instalasi yang berkembang dalam seni keramik kontemporer Indonesia sepanjang perjalanannya dapat dibagi menjadi dua, yaitu keramik instalasi figuratif dan keramik instalasi non-figuratif. Keramik instalasi figuratif adalah karya instalasi yang terdiri dari keramik-keramik figuratif, yang disusun/dipasang sesuai konsep seniman sehingga menghasilkan makna baru. Jenis keramik instalasi berikutnya adalah keramik instalasi non-figuratif, yaitu keramik instalasi yang tersusun dari berbagai objek yang lebih bebas dan non-figuratif yang memiliki konteks atau makna tertentu. Keramik instalasi secara umum biasanya juga merupakan mix media antara keramik dengan media-media lainnya.

Bentuk-bentuk keramik instalasi dapat dikatakan tidak terbatas, namun secara historis keramik instalasi yang berkembang di Indonesia pada mulanya adalah penggunaan material tanah liat atau idio-idiom yang menegaskan tanah liat sebagai bahan dasar keramik. hal itu dapat dilihat pada penggunaan batu bata atau gerabah pada karya-karya instalasi. Keramikus mapan yang kerap dan terkenal dengan keramik instalasinya adalah Hendrawan Riyanto dan Ponimin, hingga seterusnya keramik-keramik instalasi semakin banyak dihasilkan seniman-seniman muda yang mengolah keramik menjadi media ekspresinya.

Hendrawan Riyanto adalah pendobrak keramik Instalasi Indonesia. Karya-karyanya memberikan paradigma baru dalam dunia seni keramik. Salah satu karyanya yang dapat diulas adalah keramik instalasi yang berjudul "Anak dan Ibu Bumi". Instalasi ini disusun dari material tanah, kawat dan bambu yang dikonstruksikannya menjadi suatu bentuk tugu/monumen. Material tanah liat yang digunakan adalah jenis terakota dan memiliki tekstur retakan di seluruh badan nya. Terdapat juga bagian dinding tanah yang dicat putih. Pada bagian bawah juga diletakkan bola kecil tanah liat yang juga bertekstur retak-retak.

Membaca isi atau makna karya instalasi memang tidak semudah membaca makna karya seni konvensional pada umumnya. Menyingkap konten karya instalasi Hendrawan ini dengan melihat karakter dari karya-karya sang seniman sebelumnya, dapat diartikan melalui aksen tanah merah yang retak-retak beliau ingin menyampaikan tentang renungan alam, tradisi yang dekat 
dengan budaya timur. Elemen tanah, bambu dan kawat merupakan hasil alam dan bumi, dan masyarakat dan tradisi timur sangat menghargai alam dan bumi tempat mereka berpijak.

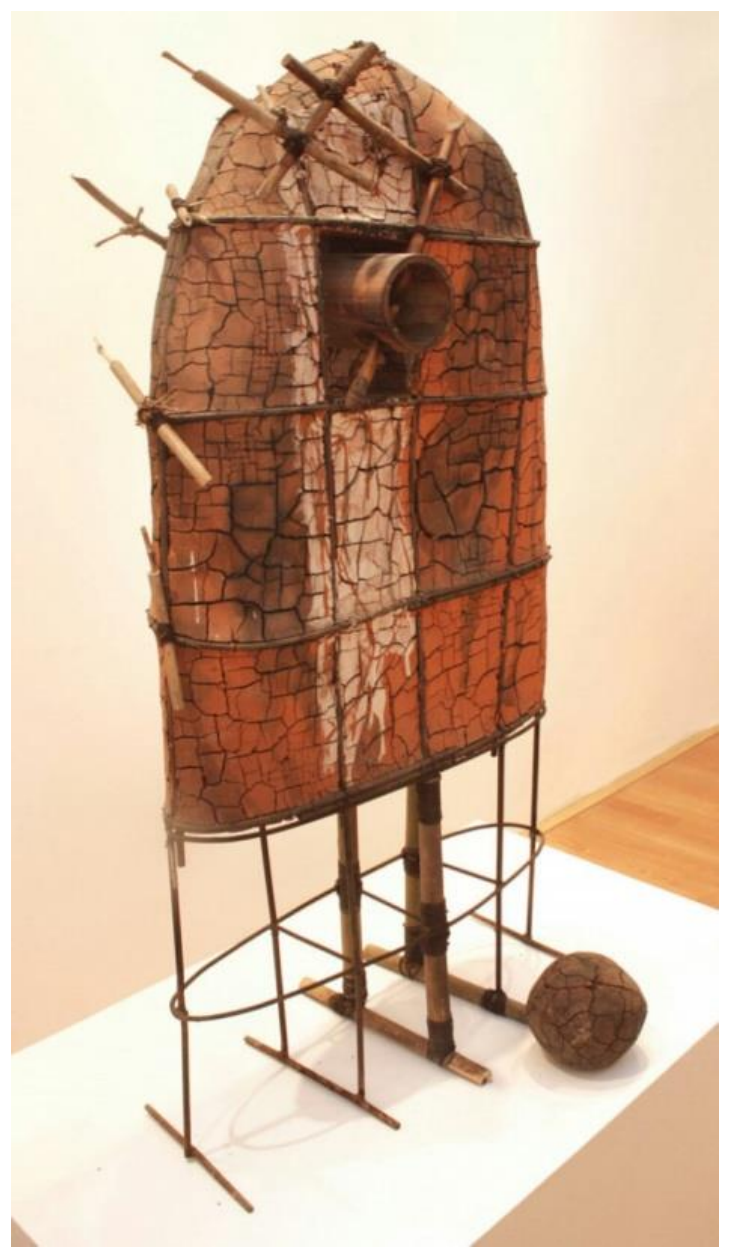

Gambar 8. Anak dan Ibu Bumi, assemblage (terracotta, bamboo, iron, wall paint), $110 \times 60 \times 23 \mathrm{~cm}$

Retakan-retakan tanah yang natural memang menjadi ciri khas karya Hendrawan. Hendrawan Riyanto dengan berbekal pemahaman formalis yang tinggi, mampu mengolah objek-objek berbahan gerabah, yang diikat dengan kawat dan ikut dibakar, sehingga memunculkan retakan-retakan spontan yang harmonis (Hendrawan Riyanto, 2012:54-55). Walaupun dengan tema yang beragam, bentuk-bentuk keramik instalasi seperti ini sampai sekarang terus bermunculan seperti yang dapat dilihat pada karya Purnomo dan Yuki Agriadi. Selain itu dengan berkembangnya seni media baru diprediksi keramik instalasi dengan bentuk dan mix media yang baru akan terus bermunculan.

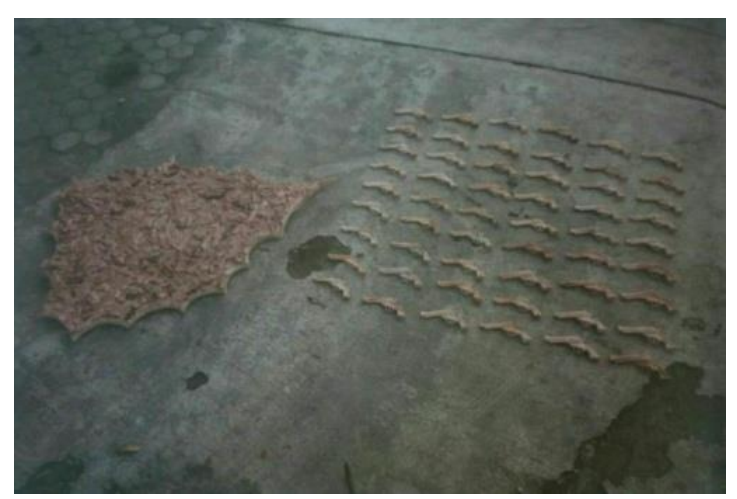

Gambar 9. Purnomo "DORRR, Stoneware 900 Celcius, Blockboard, $350 \times 126$ cm, 100 pcs pistols, 2014

Karya Purnomo yang berjudul "DOOR" pada gambar 9 diatas dipamerkan pada tahun 2014. Karya instalasi ini terdiri dari 100 buah pistol utuh dan dan lempengan sekumpulan pistol hancur. Instalasi Purnomo ini merupakan contoh instalasi keramik squlpture yang mengakomodasi simbol-simbol. Dari segi isi atau makna Pistol yang identik dengan kriminal dan kekerasan namun dapat ditampilkan juga dengan bentuk yang hancur. Purnomo memvisualisasikan sifat destruktif dari sebuah senjata, dimana ia menghancurkan pistol-pistol keramik untuk menunjukan kerapuhan (Purnomo, 2014:30). Karya ini merupakan sebuah paradoks yang ingin disampaikan si seniman melalui karyanya. Ya, hidup memang dipenuhi berbagai paradoks yang membuat kita harus melihat sesuatu dengan lebih dalam. 


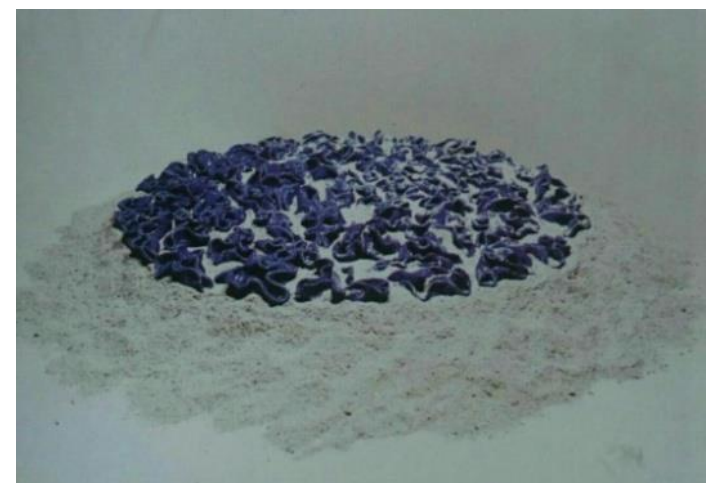

Gambar 10. R. Yuki Agriadi, "Islet of Bloom" handbuild stoneware cobalt glazed 1210 C, $75 \times 75 \times 15 \mathrm{~cm}, 2014$

Kecenderungan keramik instalasi dalam seni keramik kontemporer Indonesia berikutnya dapat dilihat pada keramik Ponimin. Berbeda dengan karya instalasi Hendrawan diatas yang condong ke sculpture (nonfiguratif), keramik instalasi Ponimin lebih figuratif dan ramai. Instalasi keramik karya Ponimin kebanyakan merupakan susunan figur-figur keramik berupa patung-patung yang kemudian membentuk karya-karya gigantik yang berdiri sendiri maupun dipamerkan secara menggantung.

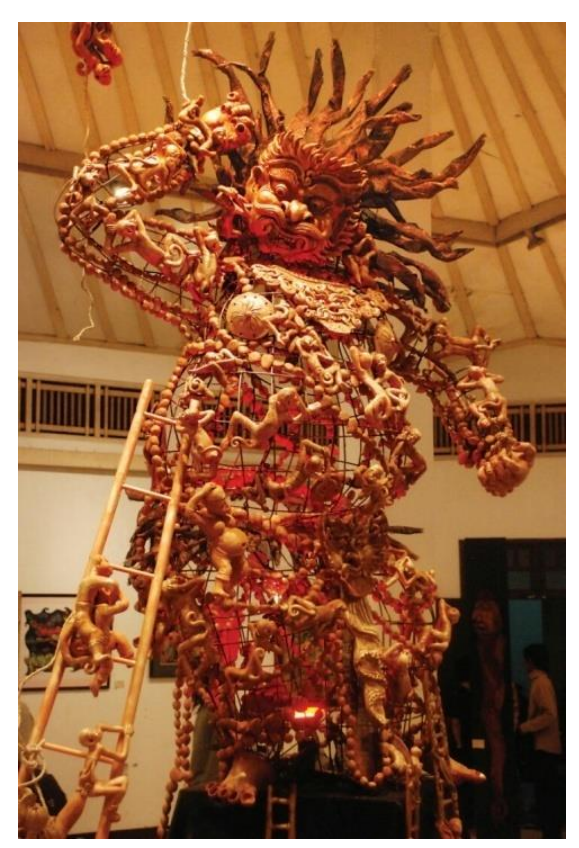

Gambar 11. Cinta Diantara Kesetiaan dan Kesia-siaan, teracota and mix media-pinch, $250 \times 300 \mathrm{~cm}, 2011$
Salah satu karya Ponimin yang dipamerkan pada JCCB \#2 adalah keramik instalasi yang berjudul "Cinta Diantara Kesetiaan dan Kesia-siaan" seperti yang terlihat pada gambar 11. Instalasi ini terdiri dari susunan terakota berupa kera-kera kecil dalam jumlah banyak yang terpasang pada kawat yang membentuk sesosok makhluk raksasa dengan tinggi lebih kurang tiga meter. Kera-kera ini nampak memanjat dan menyerang tubuh raksasa. Selain figur-figur kera pada karya ini juga terdapat aksen-aksen terakota pelengkap yang membentuk raksasa tersebut, tidak hanya itu wajah raksasa yang detail juga terbuat dari terakota.

Ponimin merupakan keramikus dari Malang yang mendapatkan pendidikan seni di ISI Yogyakarta. Karya-karya Ponimin cenderung berangkat dari tema-tema yang dekat dengan masyarakat terutama perwujudan bentukbentuk atau figur pewayangan (Khoirinnisa, Lodra, 2011:131). Karya "Cinta Diantara Kesetiaan dan Kesia-siaan" menggambarkan cerita cinta Rama dan Shinta dalam kisah Ramayana yang sudah tidak asing lagi bagi masyarakat Jawa dan Bali. Raksasa yang diwujudkan pada karya ini merupakan Rahwana yang sedang diserang oleh para pasukan kera Hanoman.

Dalam cerita Rama dan Shinta dikisahkan bahwa Hanoman membantu Rama untuk membebaskan istri yang sangat dicintainya yaitu Shinta yang diculik Rahwana. Setelah Rahwana berhasil ditaklukan oleh Hanoman dan Shinta dipertemukan kembali dengan Rama, betapa diujinya kesetiaan Shinta. Rama ternyata menolak Shinta karena berpikir bahwa Shinta sudah tidak suci lagi. Jika ditarik benang merahnya, maka potongan cerita tersebut sesuai dengan judul karya sang seniman. Tema-tema karya yang kembali 
mengangkat tradisi memang kerap hadir dalam seni rupa kontemporer. Salah satu contoh dapat dilihat pada karya-karya instalasi bambu Joko Avianto yang banyak mewarnai perhelatan seni rupa kontemporer lokal hingga mancanegara. Nampaknya pola pikir thinking globally act locally dalam berkarya merupakan salah satu ciri dalam setiap karya seni kontemporer. Karya yang berangkat dari local genius ini dapat bersumber dari material hingga cerita rakyat.

Dalam dunia keramik kontemporer Indonesia, dapat dikatakan tidak banyak karyakarya instalasi yang bentuk dan temanya serupa dengan karya Ponimin, meskipun demikian bentuk-bentuk keramik instalasi figuratif tetap berkembang pada karya-karya keramikus muda macam Fauzi Adhika dan Rosanto Bima Pratama.

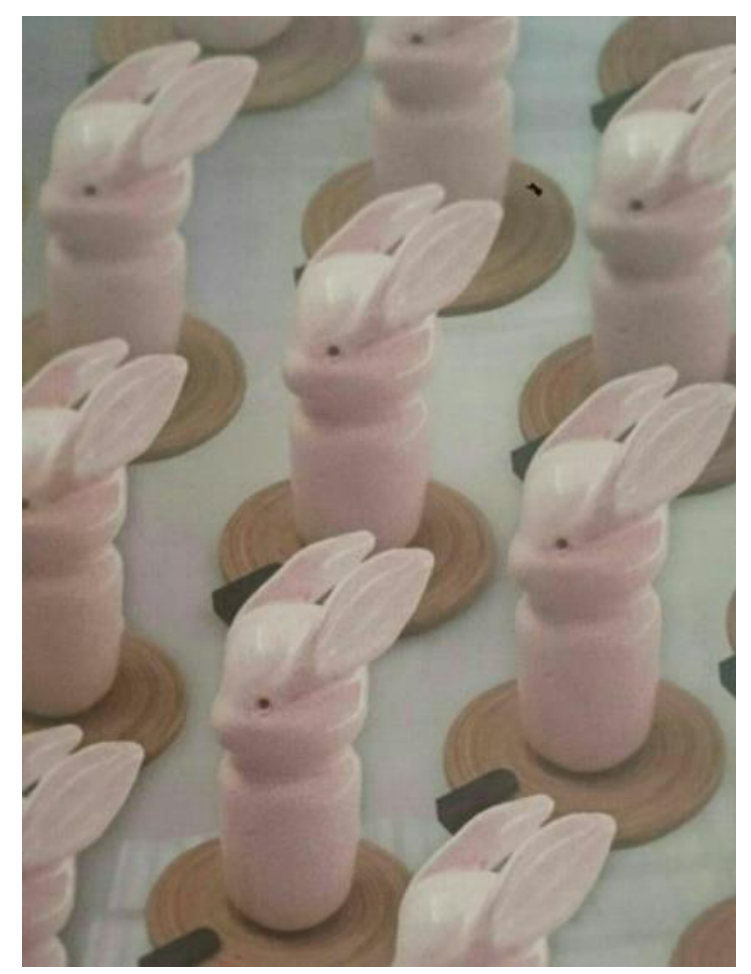

Gambar 12. Fauzi Adhika, Coefficient of Reproduction, Stoneware, 2014
Keramik Fauzi Adhika pada gambar 12 merupakan keramik instalasi figuratif dengan perwujudan figur-figur kelinci. Dari segi konten karya ini menggambarkan siklus reproduksi artefak-artefak yang simultan. Dalam deskripsi karyanya dituliskan bahwa kelinci, dengan sifat reproduksinya yang tinggi, merefleksikan beragam ide manusia untuk mencari solusi dari suatu masalah. Sementara itu karya Bima Rosanto dengan judul "The magic of Art "Abrakadabra" memiliki bentuk instalasi figur figur makhluk dari cerita fantasinya masa kecil dengan konten yang juga merupakan ekspresi personal dari pengalaman sang seniman (Fauzi Adhika, 2014:17).

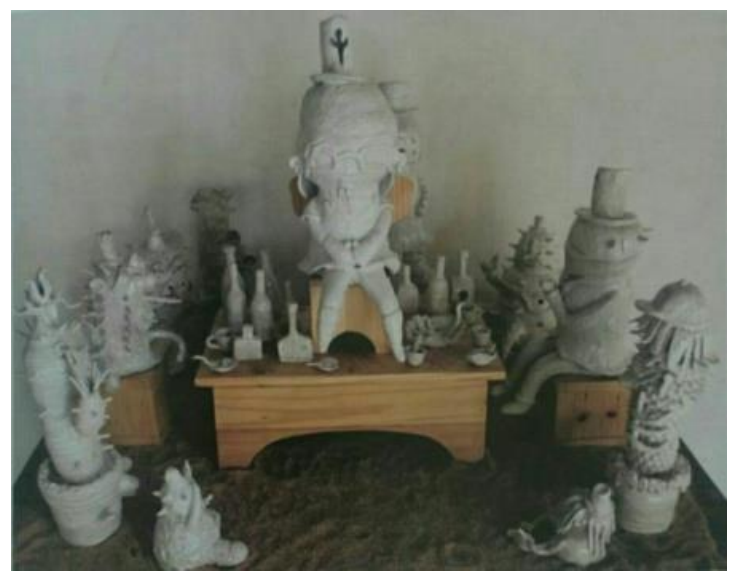

Gambar 13. Rosanto Bima Pratama, Magic of Art "Abrakadabra", Glazed Stoneware, Variable size, 2014

Kecenderungan keramik instalasi khususnya figuratif dalam dunia seni keramik kontemporer Indonesia terjadi bukan hanya karena pengaruh kuat paradigma "kebebasan" dalam seni rupa kontemporer semata, namun terdapat faktor-faktor lain. Selain pengaruh perkembangan keramik kontemporer dari luar, faktor lainnya adalah semakin banyak senimanseniman kontemporer dengan latar belakang berbeda yang bereksperimen memainkan tanah liat sebagai media seni seperti seniman Uji "Hahan" Handoko dan Eddie Hara yang 
berlatar seni murni. Paradigma para seniman ini dalam berkarya keramik tentu berbeda dengan seniman yang benar-benar belajar keramik dari awal berkarya, dimana seniman dengan basic keramik biasanya lebih terbuka pada bentuk-bentuk karya-karya keramik tradisional dan konvensional.

Satu hal lagi yang melatar belakangi keberadaan keramik instalasi adalah karena karena trend seni rupa kontemporer semakin mengedepankan semangat bahwa karya seni harus lebih dekat dengan penonton. Karya seni kontemporer saat ini berkembang dengan inovasi untuk menciptakan interaksi yang kuat antara penonton dengan karya seni. Jika dianalisis lebih cermat dapat dimengerti bahwa karya seni instalasi merupakan salah satu bentuk yang efektif mencapai tujuan tersebut. Karya seni instalasi yang memiliki kebebasan penggunaan beragam media (mix media) juga umumnya didukung dengan space yang membuat penonton leluasa mengamati dan menikmati sebuah karya seni.

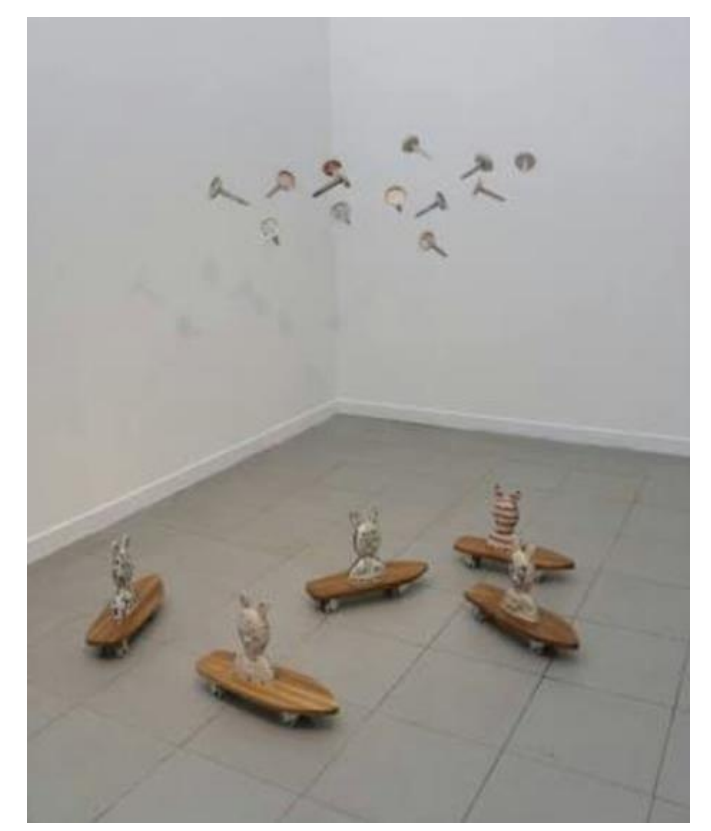

Gambar 14. Eddie Hara, "Intellectuallism Sucks, Pretend To Be Artsy, Low High Art (Nail Series), Glazed Stoneware, 2016

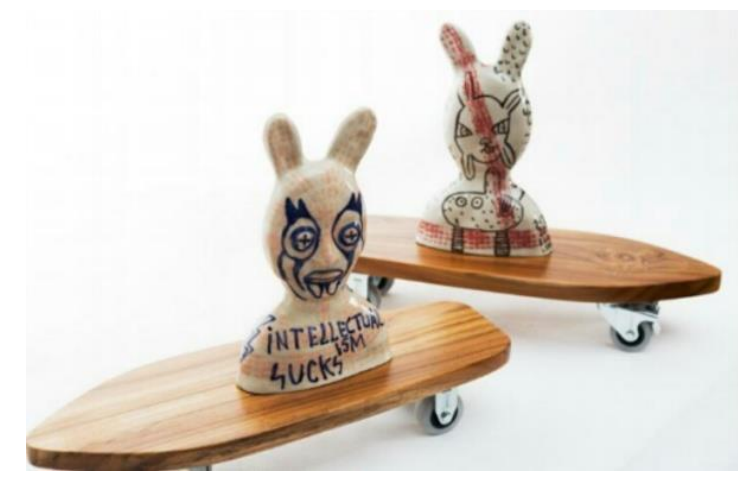

Gambar 15. (Detail karya Eddie Hara "Intellectuallism Sucks, Pretend To Be Artsy, Low High Art (Nail Series)

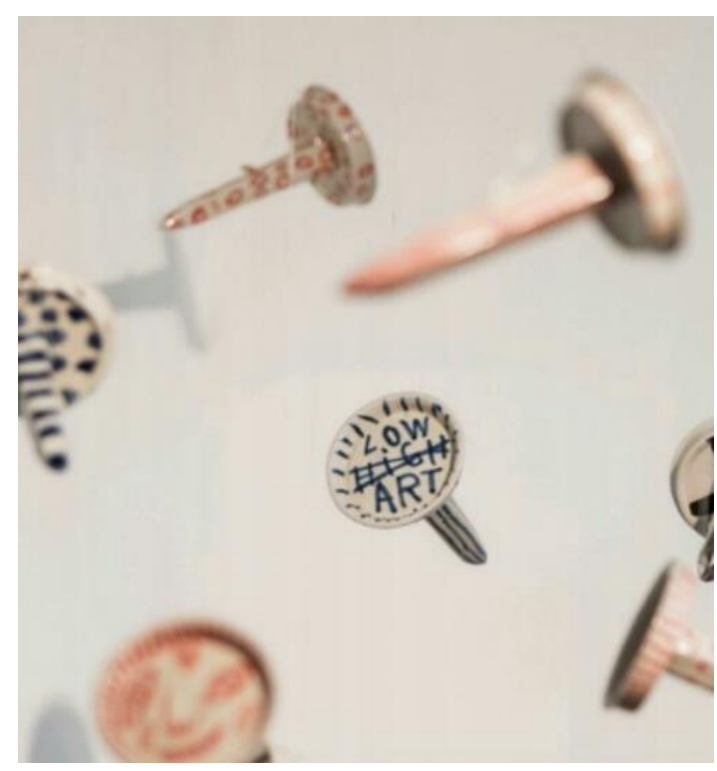

Gambar 16. (Detai karya Eddie Hara"Intellectuallism Sucks, Pretend To Be Artsy, Low High Art (Nail Series)

\section{PENUTUP}

Keramik saat ini tidak lagi identik dengan barang fungsional. Perkembangan seni rupa melahirkan keramik ekspresi sebagai media seni dan ungkapan jiwa seniman. Perkembangan ini kemudian dilanjutkan dengan kehadiran era seni keramik kontemporer. Keramik kontemporer di Indonesia cukup berkembang dengan baik. Yogyakarta, Bandung dan Jakarta dapat dikatakan sebagai wilayah yang secara berkelanjutan melahirkan seniman atau perupa keramik kontemporer. Dalam perjalanannya lebih kurang 10 tahun ini, 
keramik kontemporer dari perupa Indonesia diwarnai karya keramik dengan berbagai bentuk pengungkapan serta isi (pesan, makna, konsep) yang bergam. Meskipun demikian kecenderungan mayoritas bentuk keramik kontemporer didominasi bentuk-bentuk figuratif, squlpture dan Instalasi.

Keramik figuratif hadir karena dapat disimpulkan masih terbawa dengan bentukbentuk awal keramik modern Indonesia dan seniman-senimannya pun masih eksis hingga saat ini. Keramik squlpture yang berkembang rata-rata dihasilkan keramikus muda yang seolah-olah ingin mengedepankan bahwa nilai estetis utama dari keramik adalah keterampilan membangun tanah liat itu sendiri menjadi bentuk-bentuk estetik.

Perkembangan bentuk keramik selanjutnya mengarah paka karya-karya instalasi. Kecenderungan ini selain adanya kejenuhan akan bentuk keramik yang sudah umum, juga dipengaruhi oleh kreasi perupaperupa kontemporer yang tidak berlatar belakang seni keramik yang ikut serta mengolah tanah liat atau keramik. Di samping itu kehadiran keramik instalasi juga sejalan dengan semangat zaman yang semakin ingin menjadikan karya seni lebih dekat dengan penontonnya hingga menjadi bagian dari karya seni itu sendiri.

Seni keramik kontemporer berkembang di tengah paradigma seni kontemporer yang lebih mengedepankan paradigma form follow fun dalam berkarya. Paradigma ini kemudian memunculkan karya seni dengan berbagai bentuk pengungkapan yang konseptual dan sedikit liar. Meskipun demikian dari segi isi atau tema, keramik kontemporer Indonesia tidak serta merta mengedepankan prinsip bebas tersebut. Selain berisi ekspresi pribadi, pengalaman personal dan permainan unsur estetis, keramik kontemporer Indonesia justru masih berisi tema-tema yang berangkat dari kearifan lokal, budaya timur, hingga menyinggung isu-isu gender dan kehidupan sosial masyarakat. Uniknya, tema-tema tersebut dapat diwujudkan dengan bentuk-bentuk yang fun.

\section{Daftar Pustaka}

Dewi, C. S. (2017). Membaca Reinterpretasi Karya Joko Avianto"Strong Tree" Dalam "Roots: Indonesian Contemporary Art", Frankfurt Book Fair 2015. Jurnal Seni Rupa Galeri, 3(2), 24.

Fauzi Adhika. (2014). Coefficient of Reproduction. In N. Gautama \& S. Nuzan (Eds.), The Third Jakarta Contemporary Ceramics Biennale (1st ed.). The Ministry of Tourism and Creative Economy Republic Indonesia.

Fitriani, D. R. (2017). Food Porn: Dilema Eksotisme Dari Sebuah Makna Makanan Dalam Keramik Ekspresi. Corak, 6(1), 6575.

https://doi.org/10.24821/corak.v6i1.239 4

Hardiansyah, N. (2015). Simbolisasi Pengalaman Sosial Manusia Melalui Karakteristik Anemon Dalam Bentuk Keramik Biomimicry. Corak, 4(2), 121127.

https://doi.org/10.24821/corak.v4i2.236 7

Hendrawan Riyanto. (2012). Anak dan Ibu Bumi. In 1 (Ed.), The Second Jakarta Contemporary Ceramics Biennale.

Irianto, A. J. (2014). Ceramics Art in Context. In N. Gautama \& S. Nuzan (Eds.), The Third Jakarta Contemporary Ceramics Biennale (1st ed., p. xxix). The Ministry of Tourism and Creative Economy Republic 
Indonesia.

Louisa Taylor. (2011). Ceramics: Tools and Techniques for the Contemporary Maker (First). Words \& Visuals Press Pte Ltd.

Purnomo. (2014). DORR. In N. Gautama \& Sakti Nuzan (Eds.), The Third Jakarta Contemporary Ceramics Biennale (1st ed., p. 30). The Ministry of Tourism and Creative Economy Republic Indonesia.

Rispul, R. (2012). Seni Kriya Antara Tekhnik Dan

Ekspresi. Corak, 1(1), 91-100. https://doi.org/10.24821/corak.v1i1.231 5

Rupa, P. S., Surabaya, U. N., Rupa, P. S., \& Surabaya, U. N. (2011). KERAMIK GERABAH KARYA PONIMIN TAHUN 2011 Nurliza Khoirinnisa I Nyoman Lodra. 157, 129-132.

Salma, I. R., \& Eskak, E. (2016). Kajian Estetika Desain Batik Khas Sleman \&quot;Semarak Salak\&quot; Dinamika Kerajinan Dan Batik: Majalah IImiah, 32(2), 1-8.

Sarasvati, admin of. (2013). Menyelami jakarta Contemporary Ceramics Biennale: Dari Pemetaan Hingga Penjelajahan.

Satrio, A. A. (2013). Kriya Keramik: Wujud, Posisi, Dan Perannya Di Masa Kini. Corak, 1(2), 167-176. https://doi.org/10.24821/corak.v1i2.353

Sudjud Dartanto. (2012). Crafting Identity: Keramik Seni sebagai Arsip Pengetahuan. In H. Rolan, N. Gautama, \& E. Prameswari (Eds.), The Second Jakarta Contemporary Ceramics Biennale (1st ed., p. 16).

Yustana, P. (2012). Karakteristik Tanah Liat Dan
Pengaruhnya Terhadap Keberhasilan Warna Glasir. Corak, 1(1), 62-77. https://doi.org/10.24821/corak.v1i1.231 3

\section{Webtografi}

Lee, J. (2010). history of the jccb. Retrieved from

https://jakartacontemporaryceramic.wor dpress.com/history-of-the-jccb/jccb12009-2010/artists-2/jenny-lee/

Lestari, E. (2010). History of jccb. Retrieved from

https://jakartacontemporaryceramic.wor dpress.com/history-of-the-jccb/jccb12009-2010/artists-2/endang-lestari/

Sarasvati, admin of. (2013). Menyelami jakarta Contemporary Ceramics Biennale: Dari Pemetaan Hingga Penjelajahan. Retrieved from https://sarasvati.co.id/pameran/01/meny elami-jakarta-contemporary-ceramicsbiennale-dari-pemetaan-hinggapenjelajahan/\#

Sudjud Dartanto. (2012). Crafting Identity: Keramik Seni sebagai Arsip Pengetahuan. In H. Rolan, N. Gautama, \& E. Prameswari (Eds.), The Second Jakarta Contemporary Ceramics Biennale (1st ed., p. 16). Jakarta.

Titarubi. (2010). history of jccb. Retrieved from https://jakartacontemporaryceramic.wor dpress.com/history-of-the-jccb/jccb12009-2010/artists-2/titarubi/ 